Neurolmages
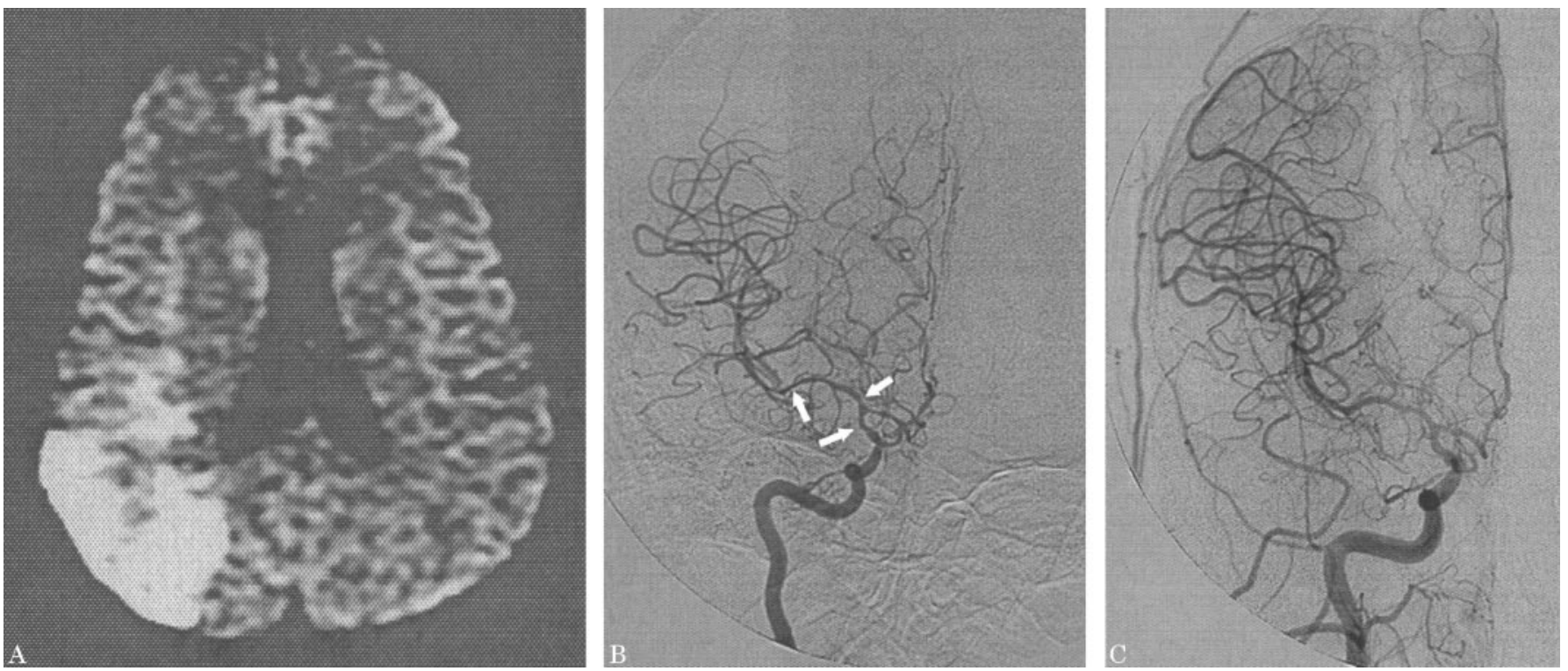

Figure. (A) MRI diffusion image shows hyperintense signal in right parietal and right insular cortex. Cerebral arteriogram (B) day 2 shows severe diffuse vasospasm involving the right supraclinoid internal carotid artery and middle cerebral artery, and (C) 41/2 months later shows normal vessel size without vasospasm.

\section{Cerebral vasospasm from sumatriptan}

S. Dash, MD; O. Bogdanova, MD; A. Xavier, MD; J. Farkas, MD; and P. Pullicino, MD, Newark, NJ

A 43-year-old woman with history of chronic migraine headache presented with sudden-onset left-sided field cut and hemiple-

Address correspondence and reprint requests to Dr. Patrick Pullicino, Department of Neurosciences, University of Medicine and Dentistry New Jersey-University Hospital, 185 South Orange Avenue, MSB H-506, Newark, NJ 07103; e-mail: pullic@umdnj.edu gia. For the previous 6 months, she had been taking sumatriptan (Imitrex) $25 \mathrm{mg}$ PO daily for headaches. MRI showed restricted diffusion in the right middle cerebral artery (MCA) distribution (figure, A). The CSF analysis was unremarkable. Cerebral arteriography revealed diffuse bilateral vasospasm involving the supraclinoid internal carotid artery, anterior cerebral artery, MCA (figure, B), and Basilar artery with its branches. There were no vascular malformations or aneurysms. Cerebral vasospasm was presumed to be from sumatriptan, and thus sumatriptan was discontinued. A follow-up angiogram done 7 days later demonstrated marked improvement. 


\section{Neurology}

Cerebral vasospasm from sumatriptan

S. Dash, O. Bogdanova, A. Xavier, et al.

Neurology 2004;63;2128

DOI 10.1212/01.WNL.0000140621.32871.18

\section{This information is current as of December 13, 2004}

\section{Updated Information \&} Services

Citations

Subspecialty Collections

Permissions \& Licensing

Reprints including high resolution figures, can be found at: http://n.neurology.org/content/63/11/2128.full

This article has been cited by 1 HighWire-hosted articles: http://n.neurology.org/content/63/11/2128.full\#\#otherarticles

This article, along with others on similar topics, appears in the following collection(s):

\section{All Cerebrovascular disease/Stroke}

http://n.neurology.org/cgi/collection/all_cerebrovascular_disease_strok e

DWI

http://n.neurology.org/cgi/collection/dwi

Infarction

http://n.neurology.org/cgi/collection/infarction Migraine

http://n.neurology.org/cgi/collection/migraine

MRI

http://n.neurology.org/cgi/collection/mri

Information about reproducing this article in parts (figures,tables) or in its entirety can be found online at:

http://www.neurology.org/about/about_the_journal\#permissions

Information about ordering reprints can be found online:

http://n.neurology.org/subscribers/advertise

Neurology ${ }^{\circledR}$ is the official journal of the American Academy of Neurology. Published continuously since 1951, it is now a weekly with 48 issues per year. Copyright . All rights reserved. Print ISSN: 0028-3878. Online ISSN: 1526-632X.

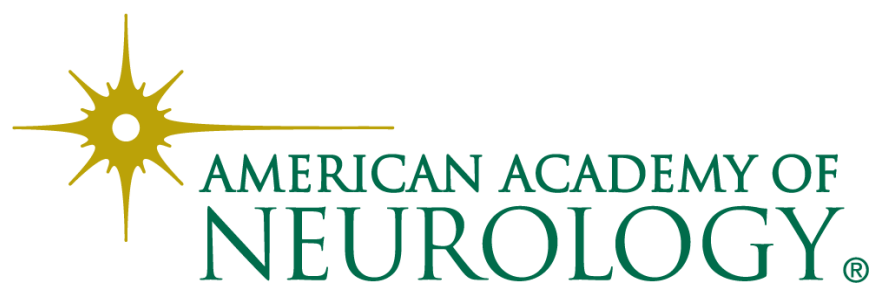

